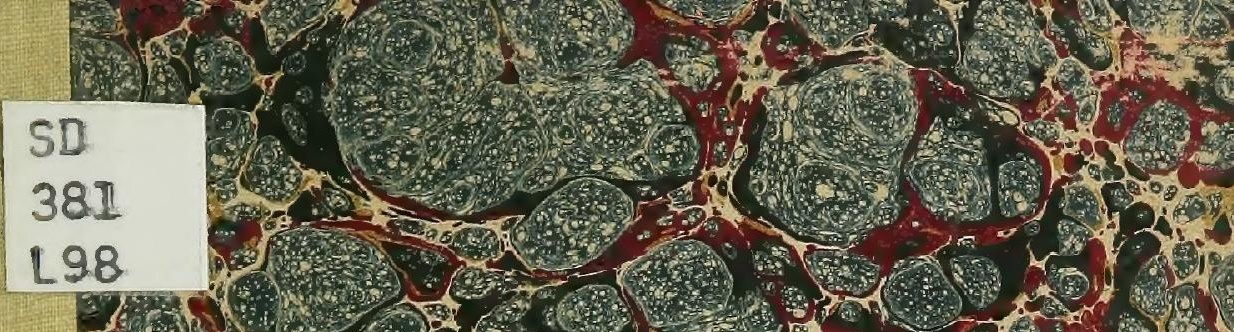

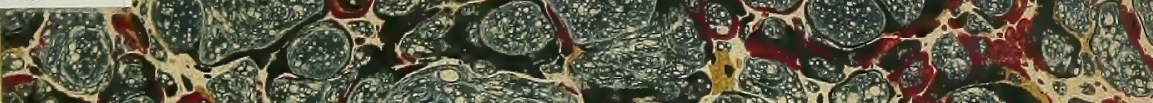
30
20

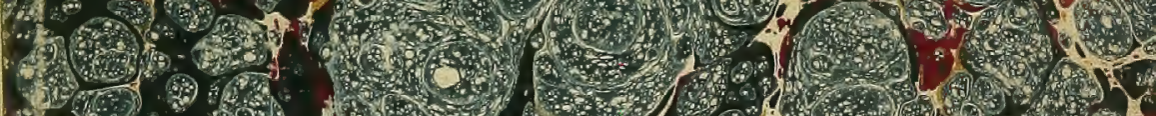

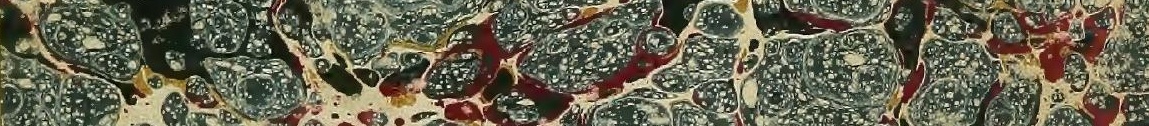

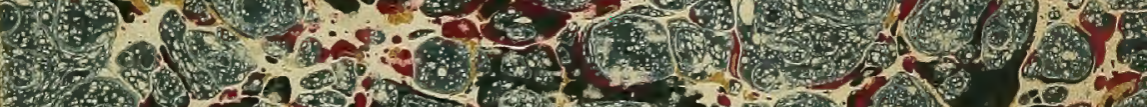
6.6.

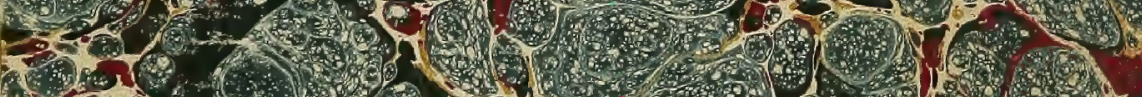
(x)

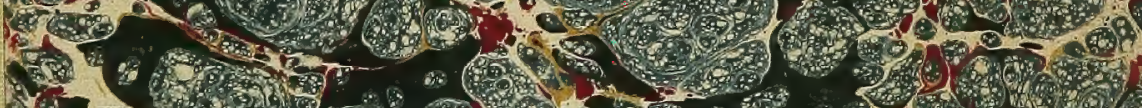

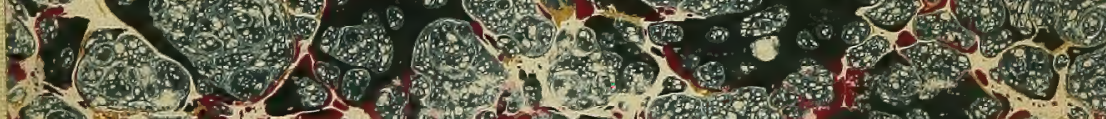

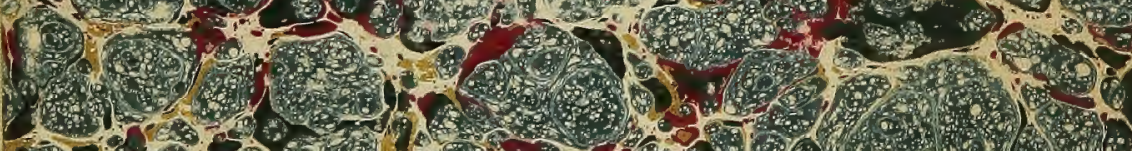
15) 3.5.

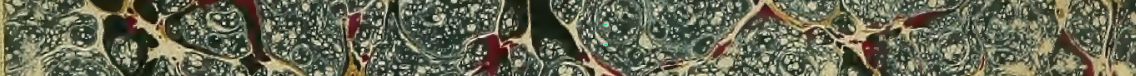

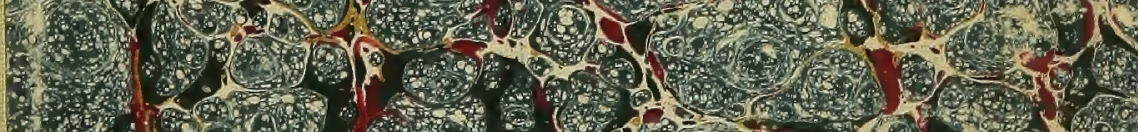
6 (6)

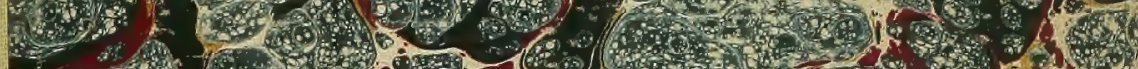

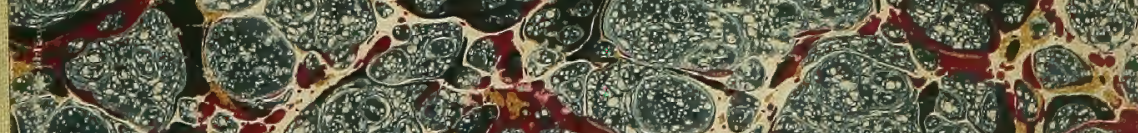

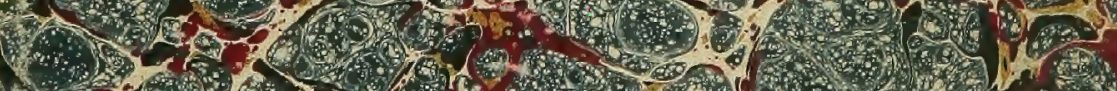

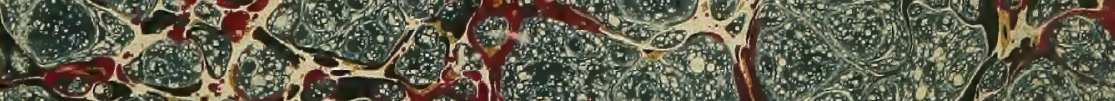

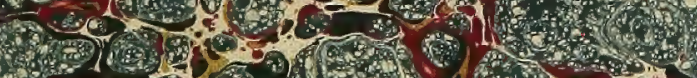
JW.Y.S.

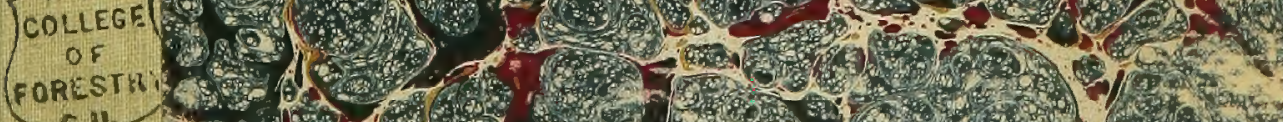
c.U. (2) (3) 


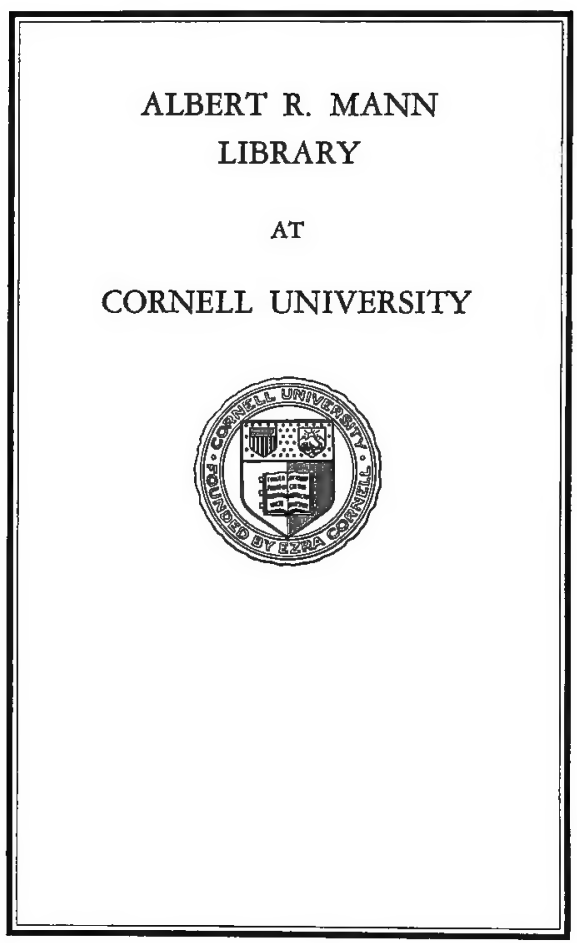




\section{A PAPER ON FORESTRY.}

SD 381.L98 98 ell University Library

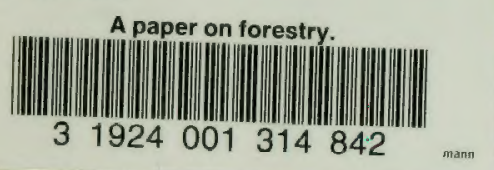

BY HON. JOHN D. LYMAN, Exeter, N. $H$.

DATE DUE

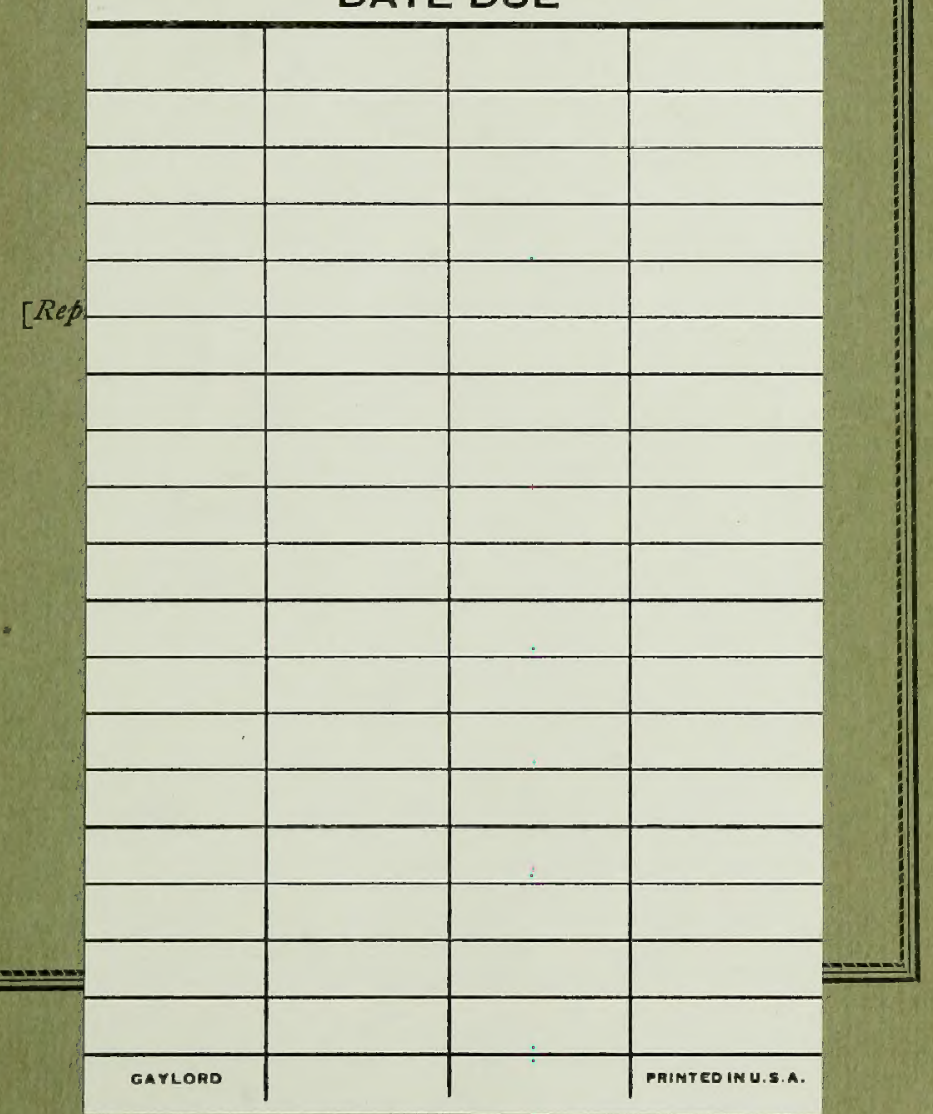




\section{Cornell University Library}

The original of this book is in the Cornell University Library.

There are no known copyright restrictions in the United States on the use of the text.

http://www.archive.org/details/cu31924001314842 


\section{A PAPER ON FORESTRY.}

BY HON, JOHN D. LYMAN,

Exeter, $N . H$.

[Reprinted from Report of State Board of Agriculture.]

CONCOR D :

REPUBLICAN PRESS ASSOCIATION.

I 897 . 



\section{A PAPER ON FORESTRY.}

BY HON. JOHN D. I.YMAN, EXETER, N. H.

I intend in this paper to further, but briefly, illustrate and enforce a few fundamental principles of forestry of which I have before treated. I am encouraged to do this by the number of groves which I see have been attended to in various and widely-separated sections of the state since this effort in behalf of for estry was commenced; and by the invitations I receive to lecture upon the subject; and letters requesting copies of my paper upon forestry, published in the last report of the Board of Agriculture (my three hundred extra copies are exhausted); and of letters inquiring for information upon certain points. These letters come not only from this and other New Eng land states, but from the central and western.

B. E. Fernow, chief of the division of forestry under our government, says that "the total annual product of wood material of all sorts consumed in the United States may be valued, in round numbers, at one billion $(\$ r, 000.000,000)$ dollars, or, roughly speaking, twenty-five billion $(25,000,000,000)$ cubic feet of wood, the annual increase of five hundred million acres of forest in fair condition. This value exceeds ten times the value of our gold and silver output and three times the annual product of all our mineral and coal mines put together. It is three times the value of our wheat crop, exceeds the gross income of all the railroads and transportation companies, and would more than wipe out the remaining public debt of the United States." (See Bulletin No. 5.) One of the most marked distinctions between the enlightened and the savage peoples is, that the latter depend almost entirely upon the spontaneous, wild production of nature for their food and clothing, while the former assist nature, and by this means increases the 
food and clothing materials thousands of folds. Instead of having herds and flocks of domestic animals, our Indians depended upon the wild animals for their meats, and chiefly upon acorns, nuts, and roots, with fish, for their other foods, and upon skins, grasses, and bark, instead of cotton, wool, silk, and linen, for their clothing. Although the present territory of the United States had three kinds of native apples, I am not aware that any Indian ever conceived the idea of having an orchard or of improving the fruit. Although plums, currants, strawberries, and other delicious fruits, grew wild in small quantities in the few open places, yet we are not aware that our Indians ever conceived the idea that they could increase the quantity or quality of these fruits by assisting nature. They plucked or slew what grew wild, and submitting to their fate, starved when nature's limited supply was exhausted. It took a great many acres of land to support one Indian and all New Hampshire supported but a few thousand.

Now, while we assist nature, and by so doing produce farm crops and domestic herds and flocks that would have astonished the most enlightened nations of the world a few years ago by their abundance and quality, yet we, strange to say, savage-like, depend upon unassisted nature to produce our wood and timber. We utterly discard the theory, in general, of the savages in regard to depending upon unassisted nature to grow our needed supplies of food and clothing materials, but when we come to the needed supplies of timber, we, like the Indians as to other crops, depend upon unassisted nature. Just as though man cannot grow a timber tree as well as he can grow an ear of corn! Just as though he must let ninetyand-nine worthless trees occupy his land to each valuable one! Just as though he must let worthless weed-trees like the little red cherry, grey birch, alder, and the like, cover his grounds instead of the white pine, the oaks, the chestnut, the ash, and other valuable trees! Just as though he must let his old fields and pastures be partially covered by the worthless, scattering, limby white pines instead of planting the seed and growing this, the most majestic of our trees, in its perfection and great value! Just as though man has not the wit and wisdom to 
mould and shape the tree, when it is growing, as easily as the potter moulds the clay! Just as though he cannot dictate to his lands whether they shall grow the worthless or the valuable trees, just the same as he can dictate to them whether they shall grow weeds or grain!

To illustrate, if you have forty young white pines growing at equal distances from each other on an acre of land, you will grow forty wide-spreading limby and nearly worthless trees. If you have ten thousand young pines of the same age on an acre and let them all remain, you wait nearly a century to get trees of the proper size for fence poles. Careful measurements and counting of annual rings, by Austin Carey, Esq., show that the spruces, six inches in diameter, four feet from the ground, in our old forests average about one hundred years of age. If you judiciously thin the acre of thick pines from time to time, you will by the time they are from fifty to seventy-five years of age have the trees average from three hundred feet to five, six, or even seven hundred feet of inchboards. And if you carefully prune off the limbs as fast as they die, and in some instances a little faster, your butt logs will be entirely free from knots, except very small ones very near the heart. If you do not prune young trees even the butt logs will generally be pretty full of black knots, which all know greatly diminish the price and the value of lumber for many purposes. I find white pine boards in our village, selling from eight dollars for a thousand feet of inch-boards to sixty dollars per thousand feet. There is no reason why you cannot at an expense of about one and a half cents to a tree, prune young trees which you select to let stand for saw-logs, so that the butt-logs will make perfectly clear stuff to within two inches or less of the heart. I have known dead pine limbs, not much larger than a pipe stem, to remain on a tree some fifty years, causing a black knot in all the boards on that side of the tree, to near the heart.

White pine limbs reach to the heart of the tree, as they start at top of the tree from buds, and as long as the limbs are alive they make red and fast knots, but when the limbs die the body of the tree grows yearly out over the dead, black 
limbs the thickness of the annual growth of the tree, and the knots are black and frequently loose from near the point where the limbs die.

This very important fact should be kept in mind, viz., that thick young forests will grow more cords of wood, whether the wood be in lumber or in fuel trees, by being properly thinned than they will by letting them go unthinned. The more you cut out in thinning, up to a certain point, the larger and more profitable will be your timber crop and the sooner fit to cut. The same is true of a wood crop.

This has been demonstrated by repeated experiments. All farmers know that they may have their corn, potatoes, grain, or grass so thickly seeded that the crop will be small. It is the same with the timber crop. Either too many or too few stalks of corn or number of trees to the acre diminishes the quantity of the crop. But there is this very important difference to be observed in the growing of a crop of corn and a crop of timber. In growing corn and other farm crops we start the crops with about the number of plants we expect to mature, while to grow a crop of good timber we should start with a great many more trees to the acre than we intend to grow to timber size.

This picture (see Fig. I) shows the form of the pine, spruce or hemlock when grown in open land.

The second picture (see Fig. 2) is of pines, which have grown from seed sown on poor plains, and they stand so close together that they are growing very slowly. They need to be thinned, and those selected to be grown into large trees should have their dry limbs removed. These trees have not green limbs enough instead of a surplus to be removed. The man who sowed the seed from which these pines, represented in the second picture, grew, died in $188_{3}$, and it is believed that he sowed their seed about 1870 , and yet these pines, with the exception of those on the outside, average far less than the size of common fence stakes.

The pines shown in the third picture (see Fig. 3) are believed to be younger than those shown in the second picture; but their far larger size and greater thriftiness are readily 


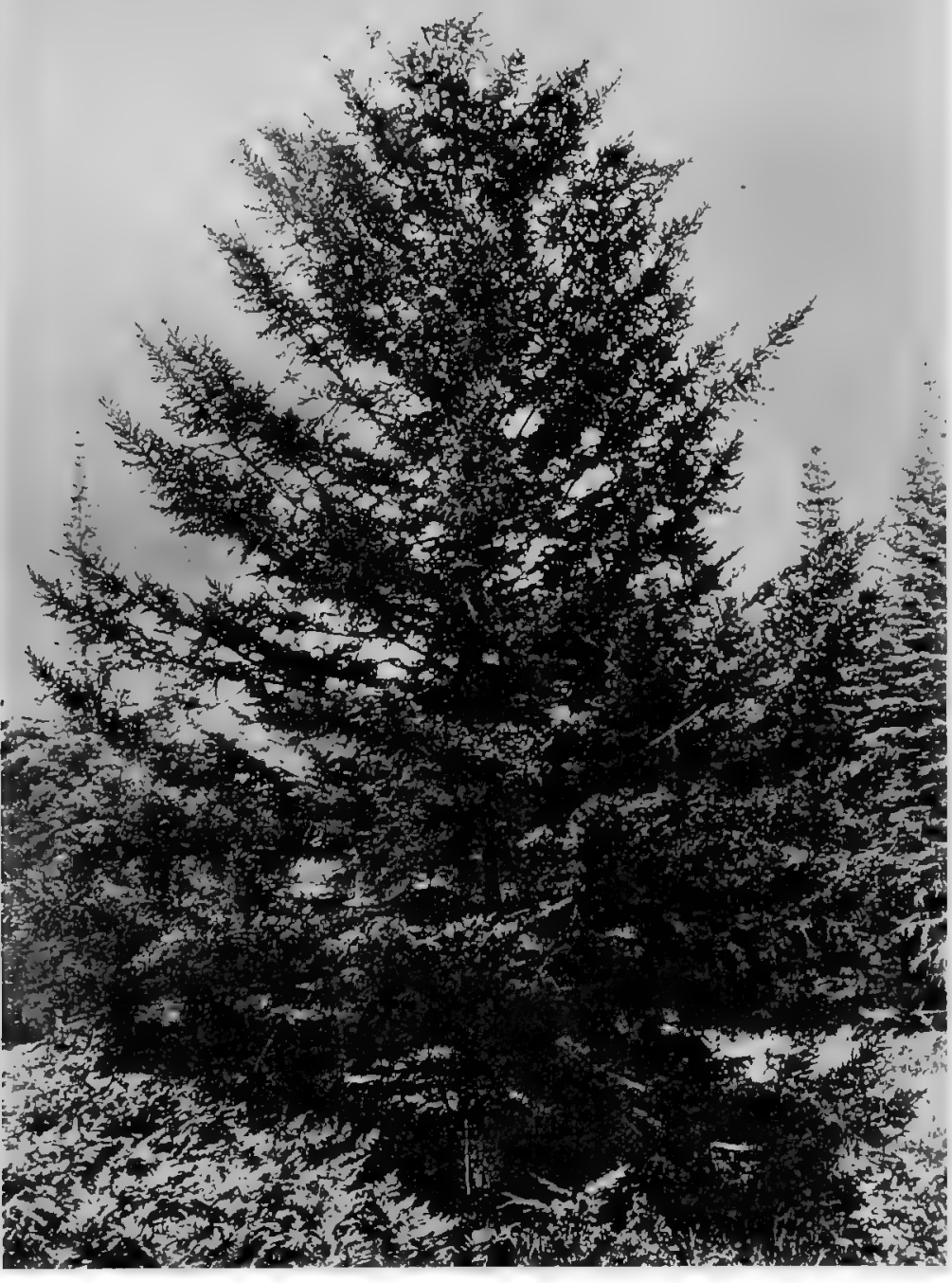

FIG. I. THIS IS A BLACK SPRUCE AND SHOWS THE FORM OF THE PINES, SPRUCES AND HEMLOCK WHEN

GROWN IN THE OPEN. 




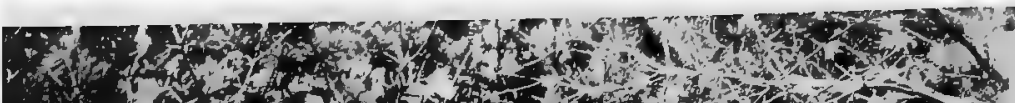

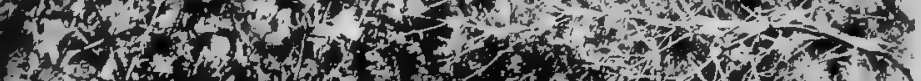

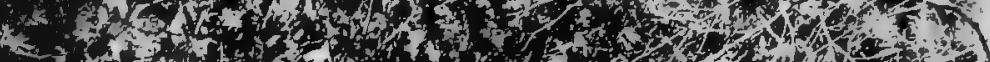

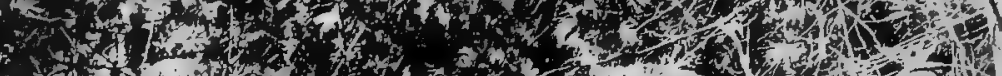

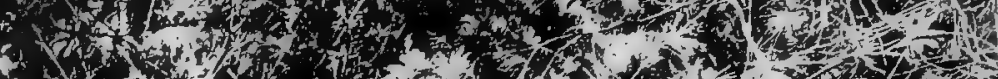

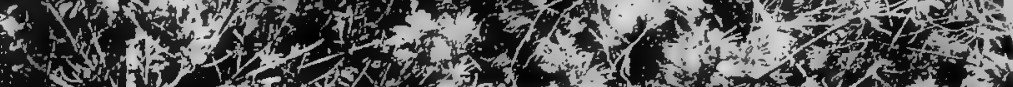

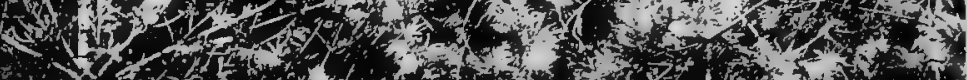

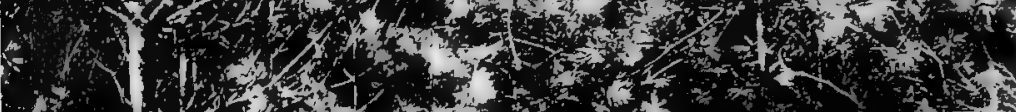
4 (1) in w

of 350

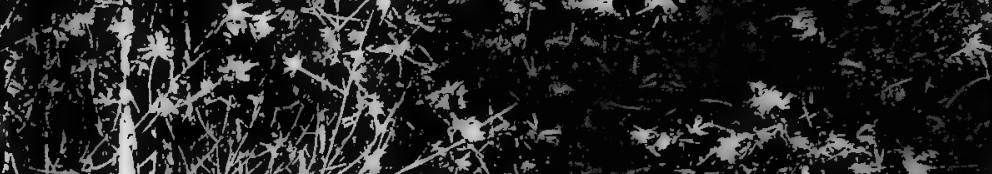

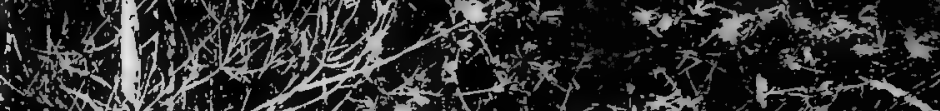

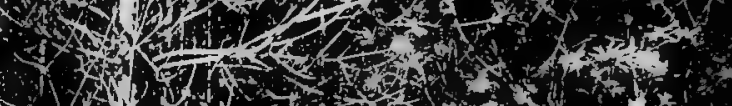

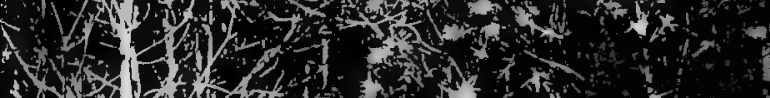

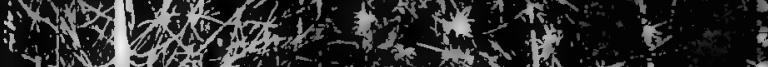

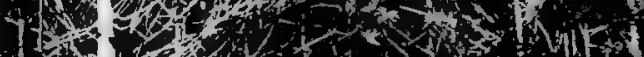

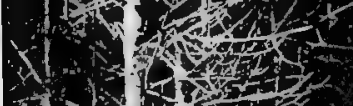

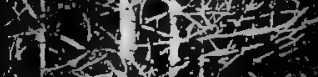

$(-\infty, 1)$

3i $13+2$

(1)

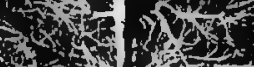

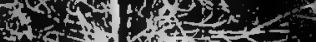

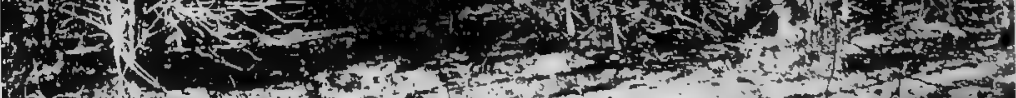

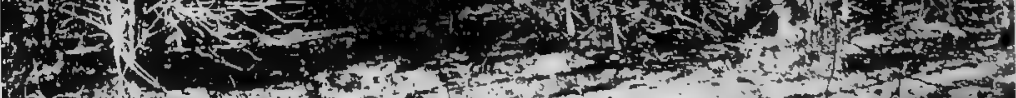

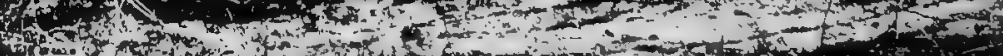

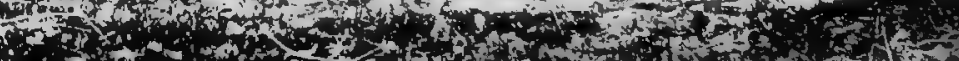

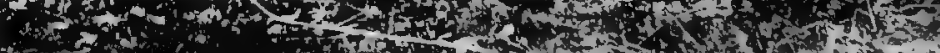

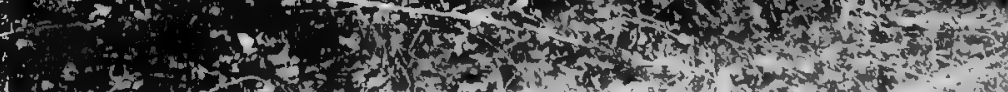

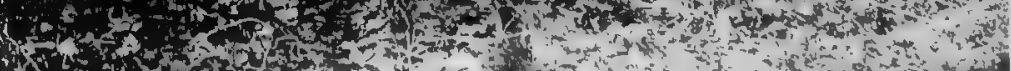

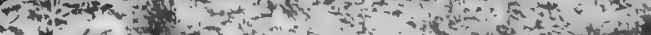

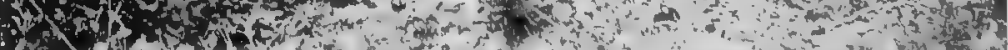
2.

FIG. 2. UNTHINNED WHITE PINES SOWN BY OMAR PEASE ABOUT I 870 . 


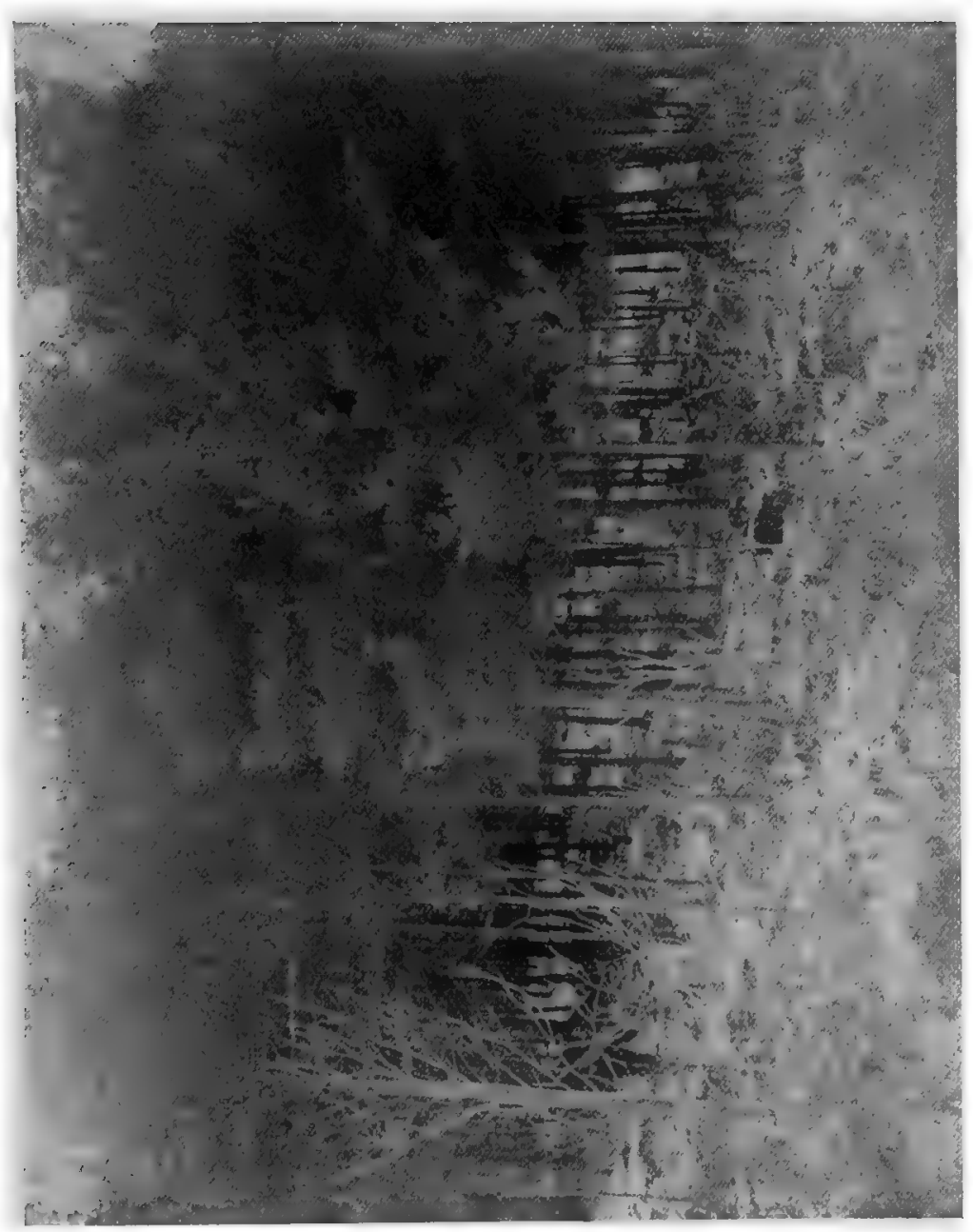

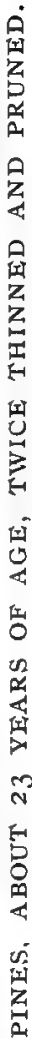

$\therefore$

它 




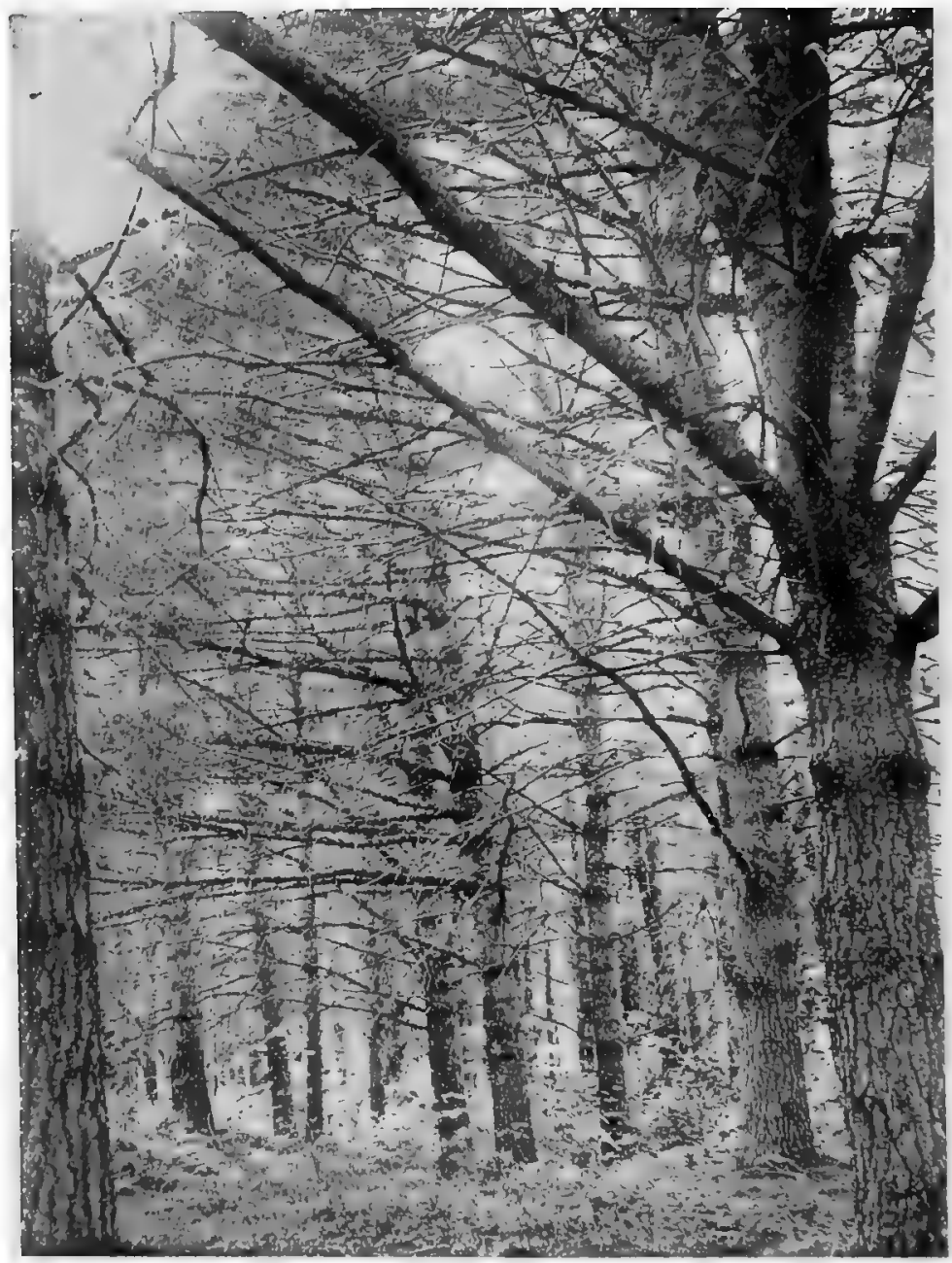

FIG. 4. NATURAL UNPRUNED PINES WHICH DID NOT COME UP THICK ENOUGH. 


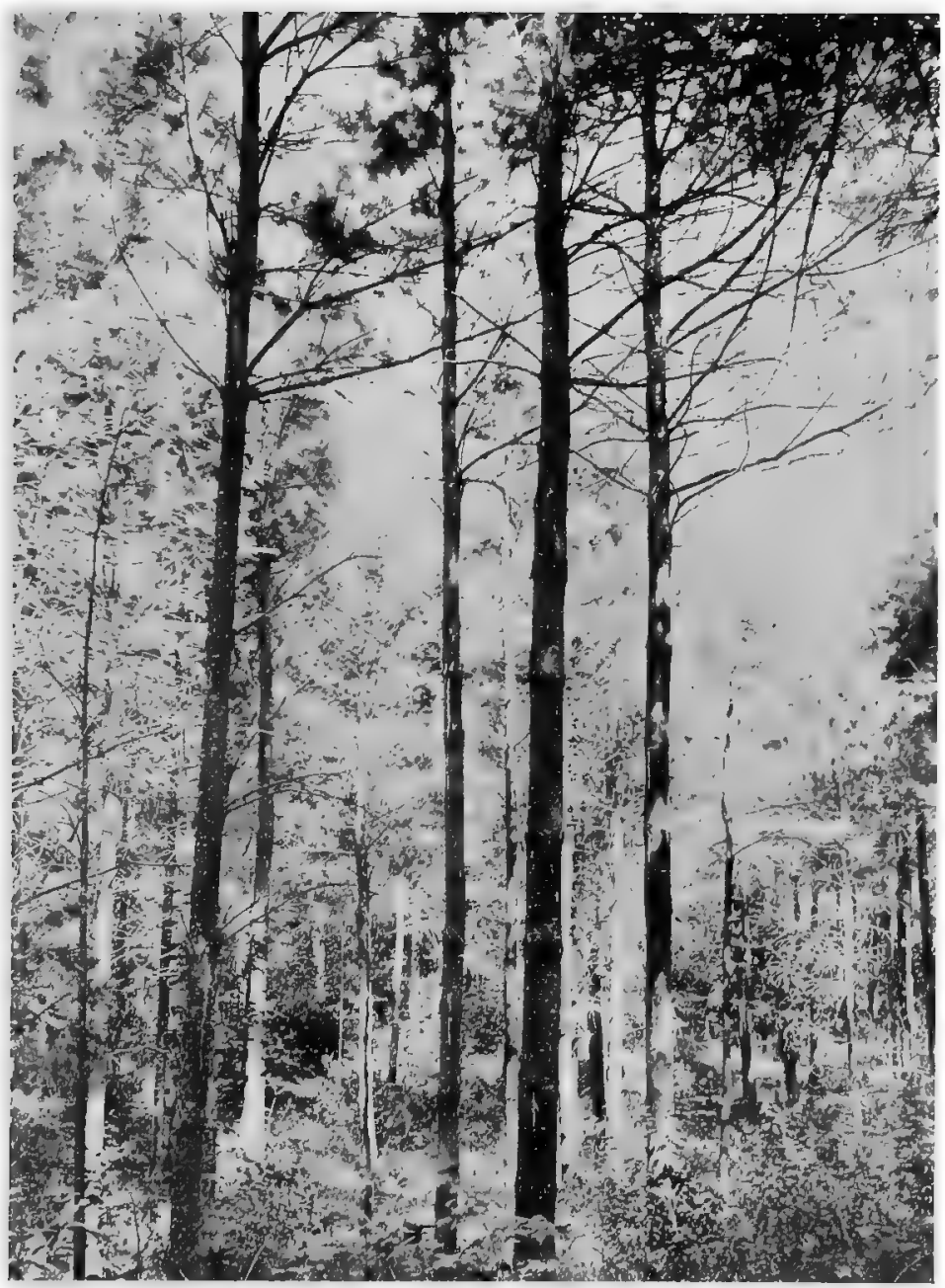

FIG. 5. PINES ABOUT SIX INCHES IN DIAMETER WHICH HAVE BEEN THINNED AND PRUNED. Porcly refuesented. 



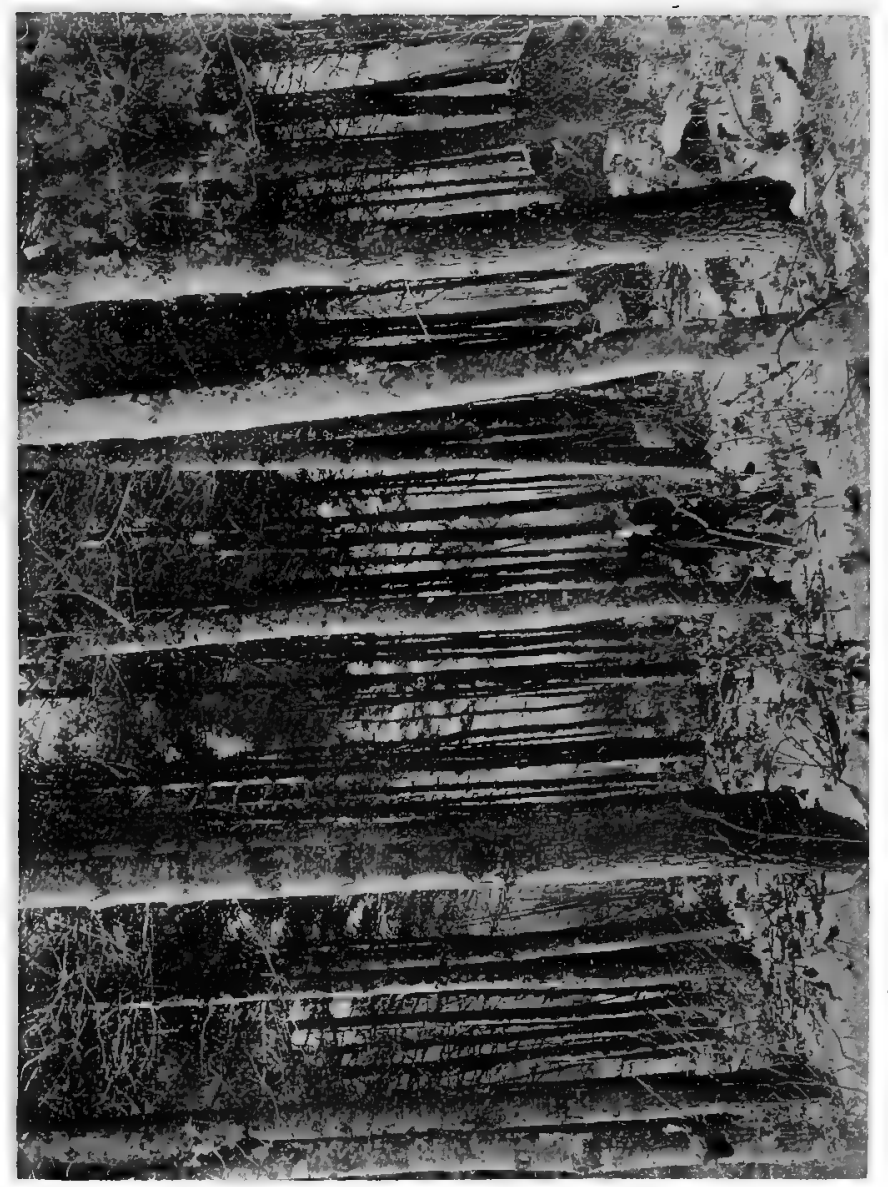

留

$0^{\circ}$

乩 

noticed. They stand on poor, high, dry land, but they have been thinned and pruned two or more times, and are consequently growing fast, and their butt logs, when sawed, will not be found full of black knots. Can any one look at the last two pictures and not be convinced of the advantages of thinning to increase the rate of growth, and of pruning to improve the quality?

The fourth picture (see Fig. 4) is of pines which did not stand so far apart as to be worthless, like the bushlike tree represented in the first picture, nor yet close enough together to make good timber. Some half a dozen years ago the axemen cut off the low limbs as far up as they could reach, which did little good save to make them look a little better. They stand on good land for pines, have grown rapidly, and will make rough, coarse, cheap lumber. Had these trees come up thick, and been properly thinned and pruned, the lumber would have been much more valuable.

The fifth picture (see Fig. 5) poorly represents pines about thirty years from the seed. They have been thinned and pruned. They are about forty-five feet in height, and their live limbs cover half or a little more of the length of their bodies. They are thrifty and handsome, and are growing highpriced timber. At sixty years of age I judge there will be fifty thousand feet of boards to the acre, and the butt logs of excellent quality.

The sixth picture (see Fig. 6) is of pines on the same abandoned farm, and standing near those represented in the fourth picture, and like them, are about fifty years of age. They came up very thick, and were entirely neglected till about twenty-four years ago, since which time they have been thinned and pruned several times. They average a little over thirteen inches in diameter four feet from the ground, and are from sixty-five to eighty feet in height. The cutting and sawing of sample trees convinces me that there is stout fifty thousand feet of timber to the acre. The quality is good, but the butt logs will not be clear of knots to so near the heart as the trees represented in the third and fifth of these pictures, because these trees were not pruned when as small as those were. 
THINNING.

Thin often so as to let the trees selected for standards ever have room to grow quite rapidly. Too much sunshine and wind must not be let in upon and among the trees at any one time by excessive thinning. Be careful to take off but few live limbs at any one pruning. Except for the expense I would cut off the live limbs at some distance from the body of the pine, and the next year prune these stubs off close to the tree. This prevents all danger of a little collection of turpentine or " pitch" at the point where the limb is severed from the tree. It is very important to have your young trees so thick that you will have no large low limbs. In this case the limbs will generally die as rapidly as it will be best to prune. I would not object to a rule which should read like this, viz.: Have your young trees stand so close together that the lower limbs will die as fast as the trees will need pruning, so as to have to prune off only dead limbs.

I am aware that some people believe that pruning trees promotes rot, and some millmen have objected to buying trees which had been pruned. My father when I was a boy pruned half or more of the live limbs at one time, from a pasture pine, which had been "slivered" in several places. The tree grew well and its body for some twenty or more feet up to the limbs, became some two feet in diameter and very handsome. A few years since its top showed signs of decreasing vitality, and upon cutting the tree it was found very rotten with the red rot. That prince of New Hampshire foresters, Joseph Barnard, Esq., reports a case where very considerable rot was reported to be found among trees which had been pruned. A newspaper writer some years since, stated that carpenters sometimes caused timber to rot by sawing it with saws with which they had sawed rotten timber; the germ or the microbe causing the decay being conveyed by the saw to the sound timber. Can this ever be the case in pruning? A member of the noted lumber company at Lisbon, told me that they found the lumber from trees which had been pruned sound. Many of my pruned trees have been cut and all found sound, and as I stated in the 
last report, I had two pines from which a hundred or more limbs had been pruned, cut and sawed into boards, and there was not a particle of rot in them. I have known instances where live limbs have been torn from trees, leaving wounds of greater or less length in the body of the tree, and for rot to begin in those wounds. A live branch some six inches in diameter was cut from a thrifty white pine, and that knot slowly rotted with a white rot which extended some two feet down into the tree. A fundamental rule in pruning, should be to remove all the live limbs, which are to be removed, when they are small, and never remove many live limbs from a tree at any one time. I have never known a tree injured by a common sense pruning. All have known fruit, shade and timber trees greatly damaged by a pruning which reminds one of butchery, and which in a lover of the beautiful God-shaped trees required a large amount of Christianity to prevent expressions unbecoming a gentleman, much more a Christian. Observation and sense are the fundamental qualifications for a forester or a farmer, and if to these be added health and industry, fires, or some such occurrences as droughts or floods, can alone prevent success, and these are not very liable to occur.

THE GROWING OF TIMBER ON WASTE LANDS.

The United States census of 1880 states that there were, at that time, one hundred and sixteen thousand acres of turned out old fields and pastures in this state, producing neither farm nor forest crop. The amount of such idle land is believed to be increasing. This land was originally covered with trees. There is no doubt whatever but the most of it is now in good condition to grow crops of white pine, and some of it other timber trees, at a great profit. A hundred thousand acres of this waste land sown to white pine seed and properly cared for, would, in from forty to seventy-five years, be worth from one hundred to four or five hundred dollars per acre, or somewhere from ten to thirty millions of dollars, at present low prices. I give a few facts to prove this statement: 
THE EXPERIMENT OF AUGUSTUS PRATT, MEMBER OF THE MASSACHUSETTS BOARD OF AGRICULTURE.

Mr. Pratt, with eight days' work, planted thirteen acres of poor land with white pine seed. The land was largely covered with blueberry bushes and small weeds. Forty years after the planting, he cut from forty to forty-five cords of boxboard logs to the acre from that land, and sold the logs, delivered at mill, for six dollars a cord. The wood brought quite a little sum. A cord of boxboard logs is said to average about one thousand feet of five-eighths of an inch thick boxboards. A great many thousand acres of better land than this lie idle in New Hampshire. Why not put it to growing timber? What a neglect of opportunity to enrich both the owners and the state! Mr. Pratt is a member of the Massachusetts board of agriculture.

OMAR PEASE.

The Shakers of Enfield, Connecticut, possess hundreds of acres of poor sand plains, in some few places too poor to sod over. Omar Pease, the head of one of the families, conceived the idea of covering these plains with white pine. He collected the seed during the first days of September, and plowed the land and sowed it to rye, and harrowed in the rye. Then he sowed broadcast two quarts of white pine seed to the acre, and rolled the ground. This course he pursued for several years as he was able to procure the pine seed. The number of acres he seeded is unknown, as it has never been measured. Judging from looks and what I was told, I estimate be seeded nearly two hundred acres. I was surprised that on these dry sand plains he succeeded every year, but such appears to be the fact. Pease died in $\mathrm{r} 88_{3}$, and his successor was unwise enough to plow up some forty acres of the youngest pines, then about a foot in height, for the purpose of growing rye. The rye failed to produce a paying crop and the ground has since lain waste. Whether Pease harvested any rye from that sown with his pine seed, I could not learn. Pease was, undoubtedly, an observing man, and had noticed that a hot sunshine directly upon the 


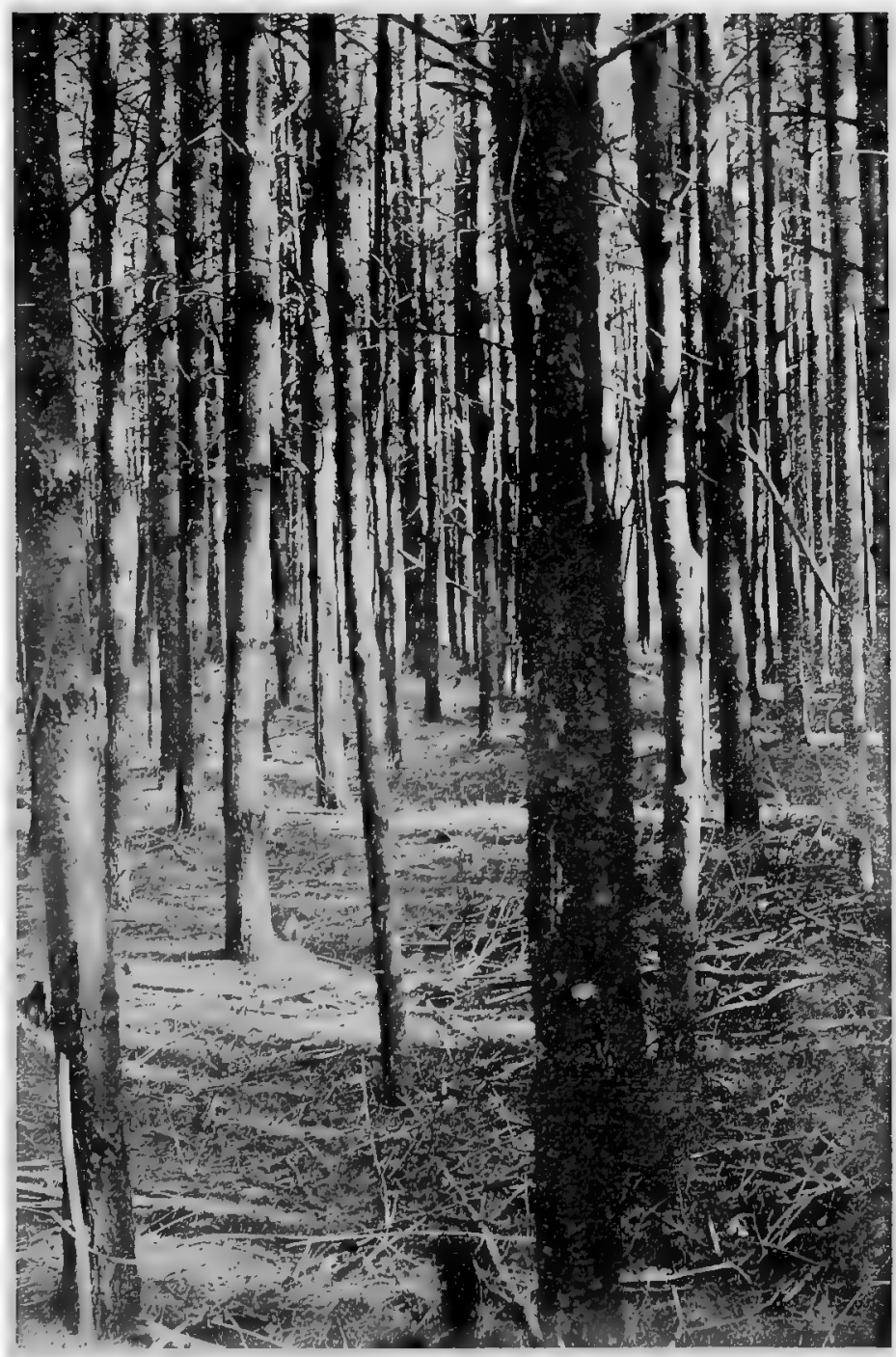

PINES GROWN FROM SEED SOWN BY OMAR PEASE UPON SAND BARRENS AND THINNED ONLY IN I896. 

young pine, the first or second year from the seed, was liable to kill it, and hence sowed the rye to shade the pine plants. The little weeds and blueberry bushes did the shading for Augustus Pratt. Although I give a picture of one place where the late sown of the Pease pines are so thick as to grow very little, yet most of them are thrifty and gain in height, on an average, about eighteen inches a year. Many acres are covered with tall beautiful trees, averaging seven or more inches in diameter, and from forty to fifty feet in height. To John W. Copley, manager for the Third family, I am indebted for much attention and information. He and the head of the Enfield Shakers readily agreed with me as to the great advantage of thinning, and, although they had never seemed to have thought of thinning before, they set about it at once, and on my second visit I found that they were thinning their trees and were greatly pleased with the operation. They were getting much wood and fencing.

They felt sure that with locusts from their plantation of that tree, for stakes, and with wire for pins instead of withes, they could, with the pine poles cut out in thinning, make a fence that would stand forty years without repairing. If any of the poles were a little too sappy, they would sslightly hew them on two sides. If all the owners of cheap and waste lands in our state could just look upon the barren plains of the Shakers, and then go into the beautiful pine plantation on just such land adjoining, they would no more doubt the practicability of covering our cheap and waste lands with timber plantations of great value than they would doubt their ability to grow a crop of corn or grass on good land.

I have before written of the success of $\mathrm{Mr}$. Jewell of Winchester, this state, who, in 1849 , gathered twelve bushels of white pine cones and sowed them broadcast on the grass sod of two and a half acres of worn-out pasture land. In I 89 I I found this a most beautiful plantation. As I remember them, the trees then averaged about sixty-six feet in height and eleven inches in diameter four feet from the ground. The cones and the little grass saved the young plants from the sunstroke. The seasons may have been favorable. 
In several European countries and in southern Asia, trees are grown as a crop, and of the kind and size desired. Just think of having every tree a valuable one and all of one kind and all fit to cut and every butt log perfectly clear, except knots not much larger than a pipestem, and these confined to within one and a half or two inches of the heart! Lumbermen have recently informed me that boards averaging from twelve to fifteen inches in diameter, from such butt logs, would in these days of cheap lumber sell for thirty dollars per thousand feet.

Sow the seed or take proper care of your close-set little pines, and it will not be many years before there will be some thirty thousand feet of such butt logs to the acre, worth say twenty dollars per thousand on the stump, or six hundred dollars beside all the other logs. Do not say that it cannot be done. It is entirely practical. Ask Vanderbilt, ask Bismarck, ask the Duke of Athol, ask Gladstone, ask any of the real estate owning nobility of England, ask any forester in Europe, ask the forest schools of the old world-all, all of these will assure you that it is one of the easiest things in the world to grow timber as a crop, and will be just as positive about it as you are that thirty bushels or more of corn can be grown on an acre of New Hampshire land. What a contrast in lumbering such plantations, compared with breaking an acre of deep snow in the mountains of northern New York to get three thousand feet of small, knotty spruce! Three thousand feet per acre is considered the average yield of timber per acre in the Adirondack region, by Superintendent Fox, and it brings one dollar and a half per thousand feet on the stump. Just think of the luxury of cutting a hundred thousand feet of first-class white pine, with every butt log clear, and the second logs nearly so, from an acre of our cheap lands instead of breaking miles upon miles of roads over many acres of land to get that amount of far poorer lumber! Yet it is entirely practical to grow a hundred thousand feet of excellent white pine timber on an acre of land. Comparatively a few years since I knew a leading farmer to plow up a few improved strawberry plants which his son had set out in the garden. The idea that one should think of cultivating strawberries! They grow wild. 
Just as absurd do many to-day deem the growing of timber as a crop as did that man of growing strawberries. Timber grows wild, they think, and so must grow ! But cultivated strawberries so supply the market now that probably multitudes have no idea that they ever grew wild. This will be the case to a great extent with timber. It will be grown and harvested as a crop, and land will be seeded to timber trees as it is now seeded to grass or planted to corn.

There appear to be about three million acres of forest land in this state, and the annual cut of timber is believed to be about one hundred feet of boards per acre on an average, and the general belief is that at this rate of cutting, our timber supply will soon be exhausted. But when these three million acres shall be covered with properly cared for timber trees there may be from five to seven times this amount cut yearly and the supply be as lasting as the sunshine and rainfall.

With all the time since the flood to operate in, unassisted nature in our White Mountain region shows a crop of about five thousand feet of spruce on the average to the acre. As I have before stated, Mr. Carey finds by cutting trees and counting grains, it takes unassisted nature about one hundred years to start a spruce in the old forests, and grow it to six inches in diameter at four feet from the ground. We think no observant woodsman will doubt but that starting spruces in cleared land, pretty close together, and properly thinning them from time to time as they begin to crowd one another, one could grow these trees at least eighteen inches in diameter in the time that unassisted nature is growing them six inches in diameter, and a log eighteen inches in diameter, it will be remembered, is nine times as large as one six inches in diameter. Of course, the eighteen inch tree would have much more than nine times as much lumber in it, because it is so much taller. When the spruce whose yearly rings are shown in one of the illustrations in this paper was given space to grow in by having the forest thinned, it grew in diameter at the rate of four inches in eleven years, and at this rate of growth a spruce one hundred years old would be three feet in diameter. At this rate the butt-log would be thirty-six times as large as the six inch log. If the trees were 
properly pruned from time to time, the clear butt-logs of fair size on the stump in the Adirondack region would be worth from ten to twenty-two dollars a thousand feet while the average price of spruce, as has been stated, is only one and one half dollars. Counting the grains of a great many spruce trees in the Adirondack region, from the heart of the trees towards the outside, the number of grains or yearly rings to the inch next the heart, was found to vary from fifteen to fortysix. But when the trees got to be a foot in diameter, with their tops above the surrounding trees, they had only from five to twenty-six grains to the inch. Nature in this clearly demonstrates the necessity of giving room to the tops of trees.

The next picture actually represents the exact rate a spruce, coming up in an old forest, did grow. You see it was many years old before it was three inches in diameter. Then its top got above some of the surrounding trees, and it grew faster till it became again crowded, and grew very slowly. Then these woods were thinned out, and this tree's top gained in size with its increased space to grow in, and the tree soon grew very fast for a spruce. This tree demonstrated, as much às any one tree can demonstrate a general principle, that thinning of thick, growing trees is of great importance.

Reckoning money at four per cent., compound interest, and saying nothing of taxes, a plantation growing a crop of timber in ninety years is worth when the trees start from the seed, thirtytwo times as much as a plantation upon which an equally valuable crop is grown in one hundred and eighty years. A good crop of white pine for merchantable inch boards can be grown in sixty years. For box boards in forty years. Starting with the trees thick and properly thinning and pruning, suppose it took seventy-two years to grow fifty thousand feet to the acre. Then you should have about twenty-five thousand feet of clear butt-logs, and the timber on the lot at present prices, would be worth about five hundred dollars per acre. Reckoning your money to have doubled thyee times, that is, for each dollar invested to have become e/\%t dollars, and dividing the five hundred dollars by eiffox, and it makes the acre of land as soon as the pine seed is in it, worth sist 6 - 


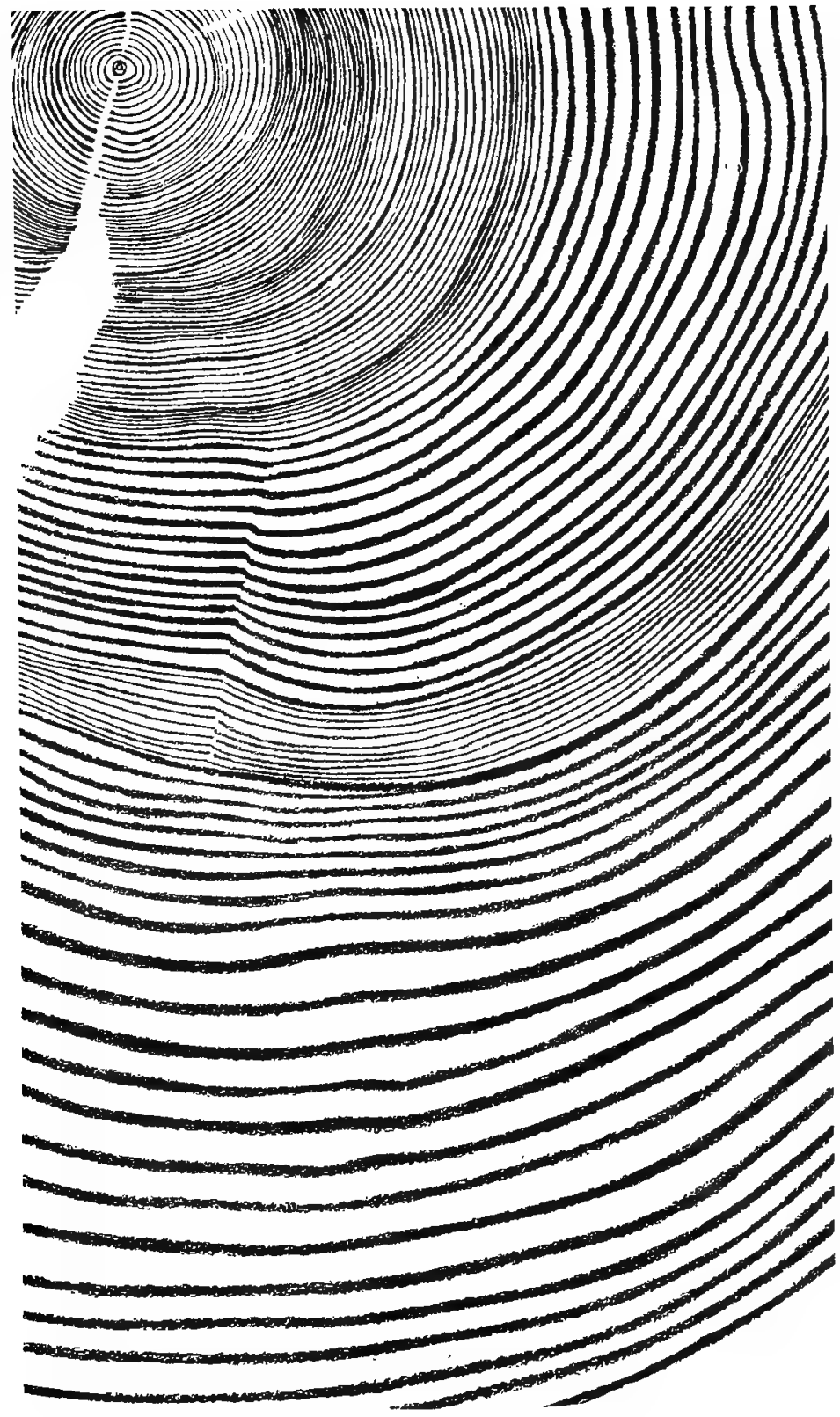


-thinnings, in many localities, for wood, fencing, shingles shook, and timber, would be worth quite a sum. I think it, safe to say that land upon which such a plantation can be grown can be bought in this state for one dollar per acre. But some one says this looks well on paper. I agree that it does, and it can be made to look better on the land. Even allow one half for the difference between theory and practice, and it looks well then. A friend of mine has lately taken two thousand dollars for the boards and shooks cut upon four acres of uncared for sapling white pine judged to be seventy-five years of age. The net income was almost three hundred and fifty. dollars per acre.

No one who has studied the growth of timber trees, and sawed them into lumber, will doubt that the value of this lot of timber could have been very much increased by assisting nature in the growth of the trees. The butt-logs could have been grown clear lumber, and the time taken to grow the trees of the size they were when cut, greatly decreased. As money at four per cent. doubles in eighteen years, every eighteen years saved in the time of growing the timber diminishes its cost by one half. Very generally, by assisting nature you can have your trees much larger at sixty years of age, than unassisted nature would have them at seventy-eight years of age, and besides the very important item of taxes, they will have cost you only one half as much. To make known the slowness of the growth of trees in the old forests, I copy a page of a table from the excellent report of Hon. William F. Fox, superintendent of the state forests of New York, to whom I am under obligation for many favors. The same table shows that the few spruces which were thirty inches in dianeter averaged three hundred and five annual rings and those thirteen inches in diameter one hundred and seventy-two and seven tenths. As the rings were counted in the stumps, which were from thirty inches to three or four feet in height, the trees were quite a number of years older than the number of rings indicates. A noticeable fact is that the trees thirty inches in diameter, which contain about eight times as much lumber as those thirteen inches in diameter, are only one and a half times as old. This teaches us to keep trees growing rapidly. 
A TABLE SHOWING THE GR()WTH OF BLACK SPRUCE IN THE OLD FORESTS OF NORTHERN NEW YORK.

\begin{tabular}{|c|c|c|c|c|c|c|}
\hline $\begin{array}{l}\text { SPECIMEN } \\
\text { NUMBER. }\end{array}$ & $\begin{array}{l}\text { Diameter } \\
\text { of stump, } \\
\text { in inches. }\end{array}$ & $\begin{array}{l}\text { Number of } \\
\text { rings on } \\
\text { stump. }\end{array}$ & $\begin{array}{l}\text { Length of } \\
\text { shaft, in } \\
\text { feet. }\end{array}$ & $\begin{array}{l}\text { Diameter } \\
\text { at top, } \\
\text { in inches. }\end{array}$ & $\begin{array}{c}\text { Number } \\
\text { of rings } \\
\text { at top. }\end{array}$ & $\begin{array}{c}\text { Total } \\
\text { height of } \\
\text { tree } \\
\text { in feet. }\end{array}$ \\
\hline $16_{3} \ldots \ldots \ldots$ & 20 & 203 & 54 & IO & 99 & 68 \\
\hline $164 \ldots \ldots \ldots$ & 20 & 207 & $\begin{array}{l}34 \\
54\end{array}$ & 8 & 124 & 71 \\
\hline $165 \ldots \ldots \ldots$ & 20 & 289 & 54 & 10 & 124 & 74 \\
\hline $166 \ldots \ldots \ldots$ & I9 & 230 & 46 & I I & I 30 & 78 \\
\hline $167 \ldots \ldots \ldots$ & I9 & 193 & 54 & 9 & 105 & 70 \\
\hline $168 \ldots . . .$. & 19 & 208. & 54 & 8 & 99 & 68 \\
\hline I $69 . \ldots . . .$. & 19 & 283 & 62 & 7 & 136 & 82 \\
\hline $170 . . . . .$. & 19́ & I94 & 54 & 13 & 100 & 70 \\
\hline $171 \ldots \ldots$ & I9 & 209 & 54 & Io & 100 & $7^{2}$ \\
\hline $172 \ldots \ldots$. & 19 & 209 & 48 & 8 & 100 & 67 \\
\hline $173 . \ldots \ldots$ & 19 & 238 & 54 & 14 & 96 & 72 \\
\hline $174 \ldots \ldots \ldots$ & 19 & 189 & 54 & I 2 & I $2 \mathrm{I}$ & 69 \\
\hline $175 \ldots . .$. & 19 & 218 & 48 & 9 & 129 & 74 \\
\hline $176 \ldots \ldots$ & 19 & 201 & 54 & II & 99 & 67 \\
\hline $177 \ldots \ldots \ldots$ & 19 & $23 I$ & 54 & 6 & 76 & 65 \\
\hline $178 \ldots . . .$. & I9 & 273 & 58 & 10 & $14 \mathrm{I}$ & 76 \\
\hline $179 \ldots \ldots \ldots$ & 19 & 194 & 54 & 9 & 100 & 70 \\
\hline $180 \ldots \ldots \ldots$ & I9 & 201 & 54 & 10 & 99 & 80 \\
\hline I $81 \ldots \ldots \ldots$ & 19 & 194 & 56 & 12 & IOI & $7 I$ \\
\hline $182, \ldots \ldots \ldots$ & 19 & 204 & 54 & 8 & 78 & 67 \\
\hline $183 \ldots \ldots \ldots$ & 19 & 207 & 54 & II & $12 \mathrm{I}$ & 71 \\
\hline $184 \ldots \ldots \ldots$ & I9 & 201 & 58 & 12 & 103 & 69 \\
\hline $185 \ldots \ldots \ldots$ & 19 & 184 & 54 & 6 & 78 & 67 \\
\hline $186 \ldots \ldots \ldots$ & I9 & $200^{\circ}$ & $4^{8}$ & 5 & 100 & 65 \\
\hline $187 \ldots \ldots \ldots$ & Ig & 201 & 54 & 9 & 89 & 70 \\
\hline $188 \ldots \ldots \ldots$ & 19 & I99 & 54 & 8 & 89 & $7 \mathrm{I}$ \\
\hline $189 . \ldots . .$. & 18 & 183 & 54 & 7 & IOI & 72 \\
\hline $190 . \ldots \ldots \ldots$ & I8 & 173 & 46 & 9 & 90 & 70 \\
\hline $191 \ldots \ldots \ldots$ & 18 & 200 & 54 & Ió & 100 & 71 \\
\hline $192 \ldots . .$. & I8 & 179 & 44 & 8 & 92 & 69 \\
\hline 193........... & I 7 & 182 & 46 & 6 & 78 & 65 \\
\hline $194 \ldots \ldots \ldots$ & 17 & 200 & 54 & Io & 89 & 65 \\
\hline $195 \ldots \ldots \ldots$ & 17 & 156 & 46 & 8 & I0O & 70 \\
\hline rq6........ & 17 & 200 & 48 & 7 & 89 & 67 \\
\hline $197 \ldots \ldots \ldots$ & 17 & 192 & 50 & Io & IOZ & 71 \\
\hline $198 . \ldots \ldots \ldots$ & 17 & 172 & 44 & 6 & 78 & 68 \\
\hline r $99 . . . \ldots \ldots$ & 16 & I7 I & $5^{\circ}$ & 5 & 79 & 66 \\
\hline $200 . . . \ldots \ldots$ & 16 & 200 & 54 & 9 & 121 & 73 \\
\hline $201 . . . . \ldots \ldots$ & 16 & 178 & 54 & 8 & 79 & 69 \\
\hline $202, \ldots \ldots \ldots$ & 16 & $20 \mathrm{~T}$ & 50 & I 1 & 99 & 70 \\
\hline $203 . \ldots \ldots$ & 16 & 167 & 44 & 9 & 100 & 62 \\
\hline $204 \ldots \ldots \ldots$ & 15 & 178 & 46 & Ió & 97 & 68 \\
\hline $205 . \ldots \ldots \ldots$ & 15 & 203 & 42 & 9 & 87 & $7 I$ \\
\hline $206 . .$. & 15 & 174 & 48 & 6 & 78 & 63 \\
\hline $207 \ldots \ldots .$. & 15 & 183 & 50 & 5 & I00 & 70 \\
\hline $208, \ldots \ldots \ldots$ & 14 & 275 & 27 & II & 155 & 74 \\
\hline $209 . . . \ldots$ & 14 & 182 & 48 & II & 108 & 68 \\
\hline $210 . . . \ldots$. & 14 & I 56 & 44 & 7 & 89 & 65 \\
\hline $211 \ldots \ldots \ldots$ & 14 & I 57 & 44 & 7 & 99 & 69 \\
\hline
\end{tabular}




\begin{tabular}{|c|c|c|c|c|c|c|}
\hline $\begin{array}{l}\text { SPECIMEN } \\
\text { NUMBER. }\end{array}$ & $\begin{array}{l}\text { Diameter } \\
\text { of stump, } \\
\text { in inches. }\end{array}$ & $\begin{array}{c}\text { Number of } \\
\text { rings on } \\
\text { stump. }\end{array}$ & $\begin{array}{c}\text { Length of } \\
\text { shaft, in } \\
\text { feet. }\end{array}$ & $\begin{array}{c}\text { Diameter } \\
\text { at top, } \\
\text { in inches. }\end{array}$ & $\begin{array}{l}\text { Number } \\
\text { of rings } \\
\text { at top. }\end{array}$ & $\begin{array}{l}\text { Total } \\
\text { height of } \\
\text { tree, } \\
\text { in feet. }\end{array}$ \\
\hline $212 \ldots \ldots \ldots$ & 14 & 200 & 54 & 5 & 78 & 64 \\
\hline $213 \ldots \ldots$. & 14 & $145^{\circ}$ & 40 & 8 & 88 & 60 \\
\hline $2 r 4 \ldots \ldots \ldots$ & 14 & 175 & 50 & 9 & 98 & 70 \\
\hline $215 \ldots \ldots \ldots$ & 14 & $16 i$ & 48 & I I & 103 & 67 \\
\hline $21 \overline{6} \ldots \ldots \ldots$ & 14 & 182 & 42 & 12 & 99 & 59 \\
\hline $217 \ldots \ldots \ldots$ & 13 & I76 & 48 & 4 & 35 & 59 \\
\hline $218 \ldots \ldots \ldots$ & I3 & 180 & 36 & 6 & 50 & 6 \\
\hline $219 \ldots \ldots \ldots$ & 13 & 157 & 42 & 7 & 60 & 57 \\
\hline $220, \ldots \ldots \ldots$ & I3 & I 50 & 28 & 8 & 76 & 57 \\
\hline $221 \ldots \ldots \ldots$ & I3 & 200 & 44 & 10 & 102 & 66 \\
\hline $222 \ldots \ldots \ldots$ & 13 & I 38 & 40 & 4 & 59 & $5^{8}$ \\
\hline $223 \ldots \ldots \ldots$ & I3 & Iб̆2 & 34 & 6 & 87 & 60 \\
\hline $224 \ldots \ldots \ldots$ & I3 & 172 & 27 & 8 & 103 & $6 I$ \\
\hline $225 \ldots \ldots \ldots$ & I3 & 192 & $3^{8}$ & 7 & 96 & 70 \\
\hline $226 \ldots \ldots \ldots$ & I3 & 200 & 44 & 9 & I 37 & 72 \\
\hline
\end{tabular}

As people quite often inquire about the difference between white and black spruce, I insert pictures of twigs from both, with cone and seed. The black spruce is the larger and more common tree in this state. With lumbermen a spruce is a spruce, regardless of whether the botanist would call it black or white. All four of the plates of the spruces used in this paper, were kindly loaned me by Hon. William F. Fox, superintendent state forests, New York. 
Fig.1. Cone and leaves, natural size.

Fig. 2 , A seed.
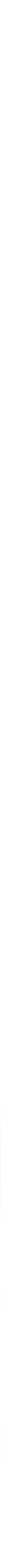



$152^{2(2)}$ (2)

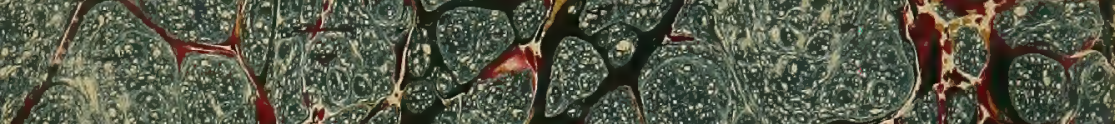

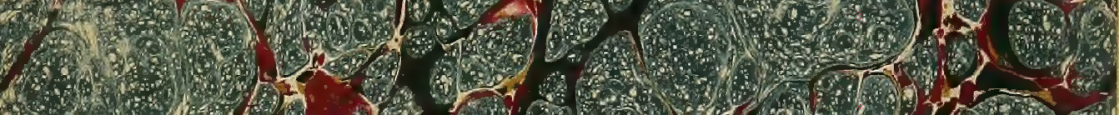

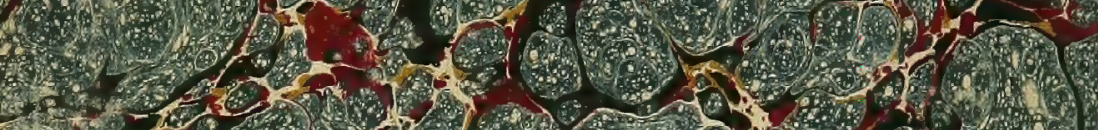
5. (6-) - $14,(5,2)$.

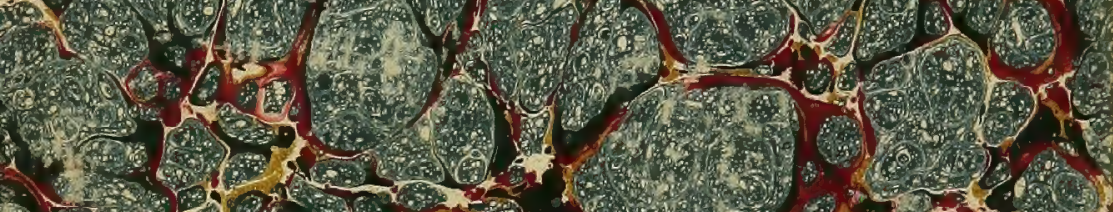
$120 y^{2}$

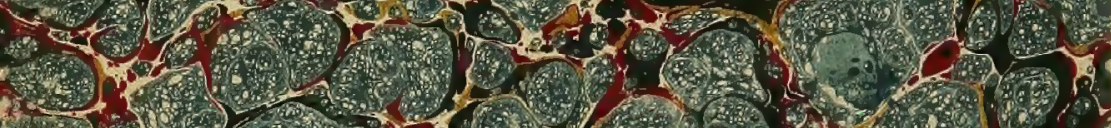
- 52 - 3.t.

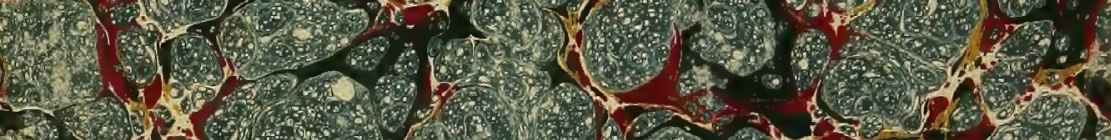
1.2.

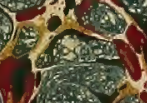
41.2 (-3.4.

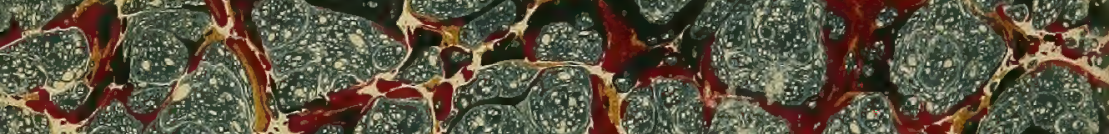

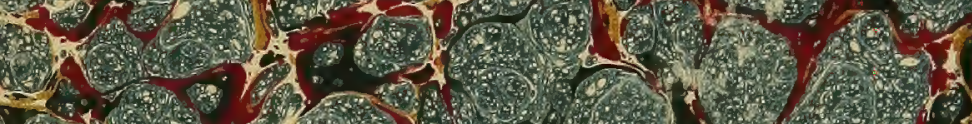
6. 2. - $^{2}$ -

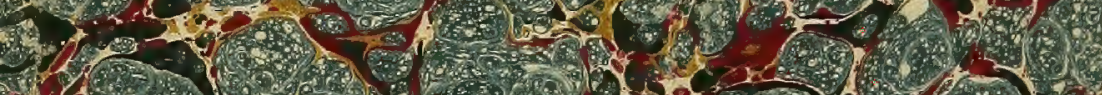

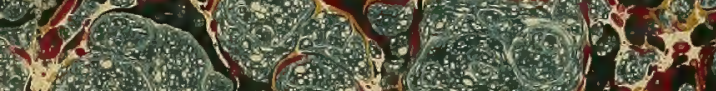

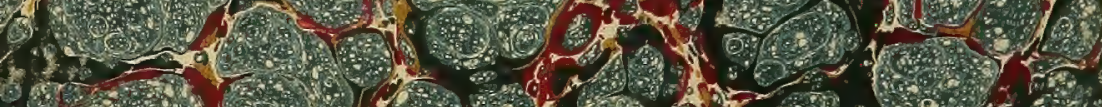

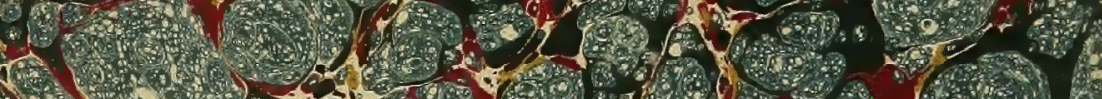

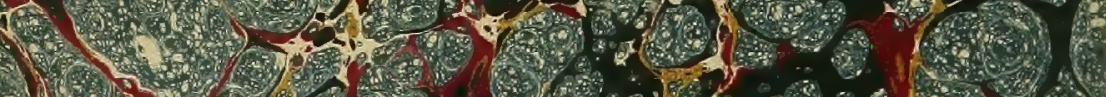

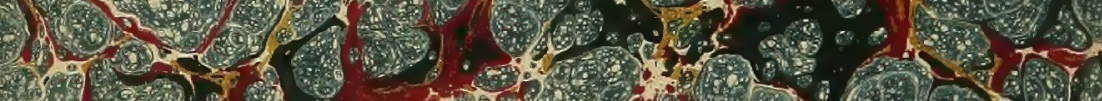

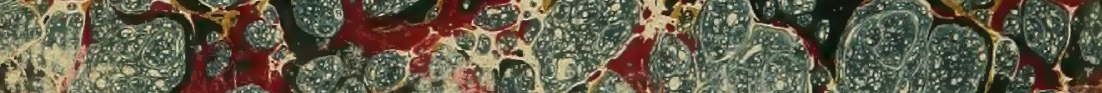

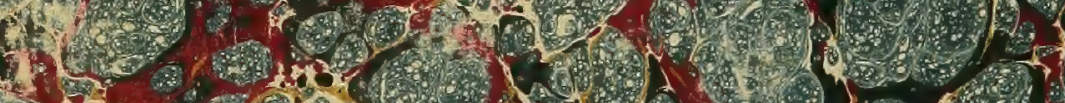
hed 